\title{
Outbreak of superficial keratitis in rubber workers
}

\author{
J. S. GROVES AND J. M. SMAIL \\ Coventry and Warwickshire Hospital
}

Numerous gases produced in industrial processes are known to cause external irritation of the eye. Unfortunately with the evolution of new techniques the possible hazards to those exposed may not at first be fully appreciated. A session on occupational hazards, physical and chemical injuries, and intoxications was held at the recent Congress of the European Society of Ophthalmology at Amsterdam in 1968 . We wish to present observations made on 32 patients from June, 1967 , to July, 1968 . They suffered from superficial keratitis as a result of working on a new method of extruding rubber strip which is mainly used as "trim" in the motor industry.

\section{Process}

Synthetic rubber and a blowing agent Genitron C.R., together with an accelerator, diethyl-thiourea, are fed into a processing machine. The above constituents are compressed into a strip of predetermined shape.

As the strip passes through a vulcanizing bed of ballotini (minute glass particles), they are heated from below by hot air at $200^{\circ} \mathrm{C}$. The Genitron C.R. decomposes to nitrogen, carbon-dioxide, and carbon-monoxide together with steam. The accelerator breaks down to release fumes of ethyl isothiocyanate in quantity and ethylamine in small amounts.

$$
\begin{aligned}
& \mathrm{C}_{2} \mathrm{H}_{5} \mathrm{NH} \mathrm{CS} \mathrm{NH} \mathrm{C}_{2} \mathrm{H}_{5}=\mathrm{C}_{2} \mathrm{H}_{5} \mathrm{NCS}+\mathrm{C}_{2} \mathrm{H}_{5} \mathrm{NH}_{2} \\
& \text { Diethylthiourea Ethyl isothiocyanate Ethylamine }
\end{aligned}
$$

On emerging from the vulcanizing bed the strip is cleaned by passing it through a water bath to remove any impurities and ballotini. Having been made into large coils, it is kept for at least 24 hours in a separate store so that any remaining fumes may escape.

Ethyl isothiocyanate or ethyl mustard oil is a moderately volatile liquid having a pungent odour and vapours which are irritating to the eyes. The liquid blisters skin (Merck Index of Chemicals and Drugs, 1960). Ethylamine has produced erosions of the cornea, conjunctiva, and lungs in experimental animals exposed to a concentration of 50 p.p.m. of the gas for a period of 6 weeks (Brieger and Hodes, 195I). Since in the above process the quantity of ethyl isothiocyanate is very large whilst that of ethylamine is relatively small, then it would appear that the former is more likely to be responsible for the present outbreak.

\section{Lesions}

Most of these workers attended the Coventry and Warwickshire Hospital complaining of pain, photophobia, and blurring of vision. The most severe cases were in those working on 
the process but less severe lesions were also observed in men who coiled the rubber. Women removing the strip from store or uncoiling it for further stages of manufacture were involved if the material had been of recent manufacture.

Examination of these patients showed the following types of lesion:

(a) Punctate epithelial erosions (PEE). These were present mainly in the interpalpebral strip but a few patients showed such lesions extending over the lower part of the cornea. The spots varied considerably in size and stained with fluorescein.

(b) Large confluent areas were found in four cases, three being bilateral and one confined to one eye. These lesions were surrounded by punctate staining.

(c) Dendriform lesions, seen in five cases, appeared as an irregular grey line of typical shape on the cornea but they stained unevenly with fluorescein. The first two of these were mistaken for dendritic ulcers caused by herpes simplex and it was only after they failed to respond to intensive IDU therapy that the diagnosis was questioned.

In the last three cases of this type virus cultures together with conjunctival and corneal scrapings were examined by an experienced virologist with special knowledge of ocular pathology. The following methods were used. The scrapings were stained by Giemsa's method and were examined under a high-power microscope fitted with $\times 5^{0}$ and $\times$ roo oil immersion objectives. No inclusion bodies were detected. Inoculations were made into HeLa MK tissue culture material and no virus was isolated. These was no previous history of virus keratitis in any of these cases. In three cases the dendriform pattern appeared about 2 weeks after the initial complaint and had been preceded by PEE. One followed the typical confluent ulcer. The dendriform pattern may therefore represent a stage of partial healing. Unfortunately it was not possible to obtain satisfactory photographs of these lesions.

All 32 lesions healed without corneal scarring and there was full recovery of function (Table). Typical corneal lesions are shown in the Figure (overleaf).

Five patients had more than one episode, but all healed satisfactorily.

Table Particulars of 32 Cases

\begin{tabular}{|c|c|c|c|c|}
\hline $\begin{array}{l}\text { Case } \\
\text { no. }\end{array}$ & $\begin{array}{l}\text { Age } \\
\text { (yrs) }\end{array}$ & Lesion (Bilateral unless stated) & $\begin{array}{l}\text { Duration } \\
\text { of lesion } \\
\text { (days) }\end{array}$ & Occupation \\
\hline $\mathbf{I}$ & 39 & Punctate epithelial erosions & $8\}$ & $\begin{array}{l}\text { Charge hand on } \\
\text { process }\end{array}$ \\
\hline 2 & 28 & Punctate epithelial erosions & 21 & Process worker \\
\hline 3 & $5^{6}$ & $\begin{array}{l}\text { Punctate epithelial erosions } \\
\text { Punctate epithelial erosions changed to dendriform pattern }\end{array}$ & $\left.\begin{array}{r}6 \\
24\end{array}\right\}$ & $\begin{array}{l}\text { Charge hand on } \\
\text { process }\end{array}$ \\
\hline 4 & 18 & Punctate epithelial erosions & 14 & Process worker \\
\hline 5 & 41 & Punctate epithelial erosions & 6 & Process operator \\
\hline 6 & 47 & $\begin{array}{l}\text { Punctate epithelial erosions } \\
\text { Punctate epithelial erosions }\end{array}$ & $\left.\begin{array}{l}6 \\
3\end{array}\right\}$ & Inspector \\
\hline 7 & 32 & Punctate epithelial erosions & 4 & Charge hand \\
\hline 8 & 40 & Punctate epithelial erosions and dendriform patterns & 14 & Process operator \\
\hline
\end{tabular}




\begin{tabular}{|c|c|c|c|c|}
\hline $\begin{array}{l}\text { Case } \\
\text { no. }\end{array}$ & $\begin{array}{l}\text { Age } \\
\text { (yrs) }\end{array}$ & Lesion (Bilateral unless stated) & $\begin{array}{l}\text { Duration } \\
\text { of lesion } \\
\text { (days) }\end{array}$ & Occupation \\
\hline 9 & 43 & $\left\{\begin{array}{l}\text { Punctate epithelial erosions } \\
\text { Punctate epithelial erosions } \\
\text { Punctate epithelial erosions } \\
\text { Punctate epithelial erosions }\end{array}\right.$ & $\left.\begin{array}{r}21 \\
5 \\
5 \\
16\end{array}\right\}$ & Process worker \\
\hline Io & 19 & Punctate epithelial erosions & 4 & Process worker \\
\hline II & 18 & Punctate epithelial erosions & 4 & Unwinding coils \\
\hline 12 & 49 & $\begin{array}{l}\text { Punctate epithelial erosions } \\
\text { Punctate epithelial erosions. Dendriform patterns later } \\
\text { Punctate epithelial erosions }\end{array}$ & $\left.\begin{array}{r}5 \\
24 \\
14\end{array}\right\}$ & Process worker \\
\hline 13 & 37 & $\begin{array}{l}\text { Punctate epithelial erosions } \\
\text { Punctate epithelial erosions }\end{array}$ & $\left.\begin{array}{l}16 \\
14\end{array}\right\}$ & Process worker \\
\hline 14 & 21 & Punctate epithelial erosions $\rightarrow$ confluent ulcers & 21 & Unwinding coils \\
\hline 15 & 26 & Punctate epithelial erosions $\rightarrow$ confluent ulcer & 14 & Unwinding coils \\
\hline 16 & 57 & Punctate epithelial erosions & 3 & Unwinding coils \\
\hline 17 & 23 & Punctate epithelial erosions $\rightarrow$ confluent ulcers & 8 & Unwinding eoils \\
\hline 18 & 18 & Punctate epithelial erosions & 14 & Unwinding coils \\
\hline 19 & 43 & Punctate epithelial erosions & 10 & Unwinding coils \\
\hline 20 & 22 & Punctate epithelial erosions (left only) & $4\}$ & $\begin{array}{l}\text { Visited process } \\
\text { briefly }\end{array}$ \\
\hline 21 & 23 & Punctate epithelial erosions & 10 & Charge hand \\
\hline 22 & 44 & Punctate epithelial erosions & 14 & Process worker \\
\hline 23 & $2 \mathbf{I}$ & Punctate epithelial erosions & 7 & Unwinding coils \\
\hline 24 & 19 & Punctate epithelial erosions & 3 & Process worker \\
\hline 25 & $2 \mathbf{I}$ & Punctate epithelial erosions & 2 & Process worker \\
\hline 26 & 18 & Punctate epithelial erosions & 5 & Process worker \\
\hline 27 & 16 & Punctate epithelial erosions (left only) & 4 & Unwinding coils \\
\hline 28 & 34 & Punctate epithelial erosions $\rightarrow$ irregular confluent ulcers & 12 & $\begin{array}{l}\text { Manager-affected } \\
\text { whilst repairing } \\
\text { process }\end{array}$ \\
\hline 29 & 30 & Punctate epithelial erosions $\rightarrow$ dendriform pattern & 35 & Process worker \\
\hline 30 & 28 & Punctate epithelial erosions & 7 & Process worker \\
\hline $3^{1}$ & & Punctate epithelial erosions & 7 & Process worker \\
\hline 32 & 21 & $\left\{\begin{array}{l}\text { Punctate epithelial erosions } \\
\text { This was followed by a confluent ulcer (left only) which } \\
\text { became dendriform in pattern }\end{array}\right.$ & $14\}$ & Process worker \\
\hline
\end{tabular}

Case nos 14 to 19 were women engaged in unwinding the coils

Cases $3,6,9,12$, and 13 had multiple episodes

\section{Treatment}

The treatment prescribed depended on the ophthalmologist who saw the case first. The following therapeutic agents were used singly or in combination:

\section{Sulphacetamide \\ Betamethasone (drops or ointment)}

Chloramphenicol (drops or ointment) IDU

None of these agents produced any curative effect although Betnesol relieved the discomfort slightly in six cases and was irritant in about the same number. 

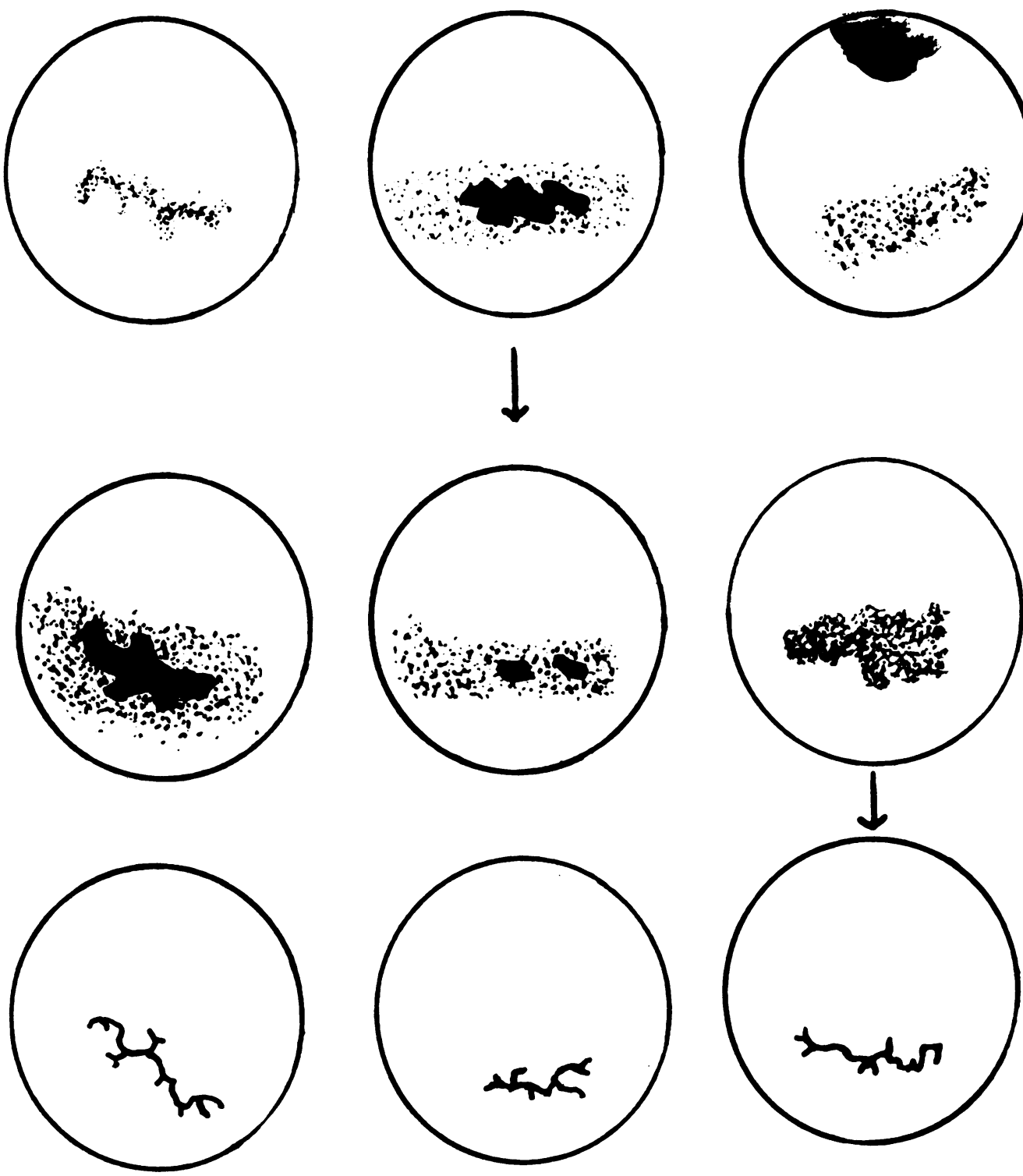

FIGURE Typical corneal lesions

\section{Preventive measures}

(I) As the fumes are heavier than air, coils of newly manufactured rubber strip are now placed on racks to allow better ventilation.

(2) Extractor fans have been installed over the process itself and in the room used for $\frac{0}{\Phi}$ storing the products.

(3) Water-spray cooling has been incorporated at the end of the process.

(4) Curtains now enclose the sides of the processing trough.

(5) Goggles have been supplied to the process workers, but these are worn only sporadic- $\stackrel{\vec{\perp}}{\stackrel{2}{\circ}}$ ally. 
It is possible that when the process was being continuously worked over 24 hours this was conducive to the concentration of fumes in the atmosphere, and the incidence of cases has been less since the continuous process was discontinued when another machine was installed. The Works Manager considers that experienced workers are less likely to be involved than those just starting in this department.

The above measures have reduced the frequency and severity of the lesion seen within the last few months.

One of us (J.M.S.) has seen two new cases from another factory in the Midlands producing synthetic rubber trim. Both showed bilateral dendriform patterns in the interpalpebral strip. They healed within about 3 weeks without scarring or loss of function.

\section{Summary}

A series of cases of industrial keratitis among rubber workers is presented. The responsible agent is almost certainly ethyl isothiocyanate. The lesions produced are described. We should particularly like to draw attention to the dendriform lesions seen in five cases which presented a diagnostic problem. Preventive measures which have now been adopted at the factory are described.

We should like to thank Mr. M. D. Kipling, Medical Inspector of Factories, for drawing our attention to this condition, Mrs. M. C. Handscombe and Mr. F. H. Budden for permission to examine their patients and for the use of their case records, and Dr. Ian Harper for examining the conjunctival and corneal scrapings. We should also like to record the co-operation we have received from the Works Manager at the factory.

\section{References}

BRIEger, H., and hodes, w. A. (195I) Arch. industr. Hyg. occup. Med., 3, 287

"The Merck Index of Chemicals and Drugs" (1960) 7th ed., Merck and Co., Rahway, New Jersey, U.S.A. 